\title{
Fractures of the mandible: a 20-year retrospective analysis of 753 patients
}

\author{
Mandibula kırıkları: 753 hastanın 20 yıllık geriye dönük değerlendirmesi
}

\author{
Teoman ESKITAŞCIOĞLU, İrfan ÖZYAZGAN, Atilla ÇORUH, Galip Kemali GÜNAY, \\ Yalçın YONTAR, Mehmet ALTIPARMAK
}

\section{BACKGROUND}

The craniofacial region is one of the most frequently injured parts of the body, and mandibular fracture is one of the commonest facial skeletal injuries. The most frequent causes of mandibular fractures are the traumas related to traffic accidents, falls, interpersonal violence, and sports activities, etc.

\section{METHODS}

Seven hundred fifty-three cases (615 male, 138 female; megan age 36.2 years) (age $>16$ ) with mandibular fracture were evaluated retrospectively. Patient records were examined in terms of age, sex, etiology, seasonal variation, fracture localization, accompanying traumas, treatment modality, and postoperative complications.

\section{RESULTS}

Traffic accidents were the most common etiologic cause in all age groups and both sexes. All cases had a total of 1090 fractures, and the most common fracture localization was the parasymphysis $(28.6 \%)$, followed by the condyle, corpus, angulus, symphysis, dentoalveolar process, ramus, and coronoid process, respectively. In 25 (3.3\%) patients with fissurelike, non-displaced fracture, only symptomatic treatment was applied. Closed reduction with elastic bandage, arch bar, quick-fix screws or Ivy Loop was the only method performed in $280(37.2 \%)$ patients. Osteosynthesis by open reduction and internal fixation (miniplates, screws or transosseous wiring) was performed in $403(53.5 \%)$ patients; closed reduction techniques were also performed in 134 of these patients.

\section{CONCLUSION}

In the recent years, double-road constructions, increased traffic audits and regulation of the traffic rules decreased the incidence of mandibular fractures.

Key Words: Etiology; mandibular fractures; maxillofacial trauma.

\section{$\boldsymbol{A M A C}$}

Kranyofasiyal bölge vücudun en sık yaralanan bölümlerinden biridir ve yüz bölgesindeki kemik yapısından dolayı mandibula kırıkları yüz yaralanmalarında sık görülür. Mandibula kırıkları en sık travmaya bağlı görülür ve bu kırıklar ile trafik kazaları, düşme, kişiler arası şiddet, spor aktiviteleri ilişkilidir.

\section{GEREÇ VE YÖNTEM}

Geriye dönük olarak 753 hastada (615 erkek, 138 kadın; ortalama yaş 36,2 yıl) (>16 yaş) mandibula kırıkları değerlendirildi. Hastalar yaş, cinsiyet, etyoloji, mevsimsel değişim, kırık yeri, eşlik eden travmalar, tedavi yöntemi ve ameliyat sonrası komplikasyonlar açısından incelendi.

\section{BULGULAR}

Trafik kazaları tüm yaş gruplarında ve her iki cinste de en sık etyolojik neden idi. Tüm olgularda toplam 1090 kırık vardı en sik kırık lokalizasyonu parasimfizer bölge idi $(\% 28,6)$, bunu sirasiyla kondil, korpus, angulus, simfizis, dentoalveolar, ramus ve koronoid kırıkları izlemekteydi. Kırık hatları nondeplese olan 25 (\%3.3) hastaya semptomatik tedavi uygulandi. Elastik bandaj, arch bar, Ivy Loop, quick fix vida ile 280 hastada kapalı redüksiyon uygulandı. Açık redüksiyon ve internal tespit (miniplak, vida veya transosseöz kablo) ile osteosentez $403(\% 53,5)$ hasta üzerinde uygulandı. Bu hastaların 134'ünde kapalı redüksiyon gerçekleştirildi.

\section{SONUÇ}

Son yıllarda, çift yol inşaatları, artan trafik denetimleri ve trafik kurallarına düzenlenmesiyle mandibula kırıklarının insidansı azalmıştır.

Anahtar Sözcükler: Etyoloji; mandibula kırıkları; maksillofasial travma. 
The craniofacial region is one of the most frequently injured parts of the body, and mandibular fracture is one of the commonest facial skeletal injuries ${ }^{[1-4]}$ due to certain structural properties of the bone. Mandibular fractures are divided into two main groups according to etiology as pathologic or traumatic fractures. Tumors, osteoporosis and diseases that affect the bony structure directly/indirectly appear as the causes of pathologic fractures. However, the most frequent causes of mandibular fractures are traumas related to traffic accidents, falls, interpersonal violence, and sport activities, etc. ${ }^{[5]}$ Traffic accidents are the most common cause of mandibular fractures in developing countries ${ }^{[2,5-9]}$ as well as in Turkey ${ }^{[3]}$ whereas interpersonal violence is the major causative factor in developed countries. ${ }^{[10-14]}$

The Department of Plastic and Reconstructive Surgery of Erciyes University Medical Faculty is situated in Central Anatolia, and since 1987, has been the only department responsible for the oral and maxillofacial trauma care of a population of nearly 10 million, in Kayseri and the surrounding area. In this series, it was aimed to retrospectively analyze mandibular fractures of patients ( $\geq 17$ years) who referred to our department and to compare this data with the literature.

\section{MATERIALS AND METHODS}

In our previous report ${ }^{[15]}$ of pediatric mandibular fractures, the age of the patients ranged from 0 to 16 years. For this reason, the present report was conducted on patients who were over the age of 16 years. The treatment of the patients was performed between January 1992 and December 2011. The data of the patients regarding age, sex, etiology, seasonal variation, fracture localization, accompanying traumas, treatment modality, and postoperative complications were collected in a database program (FileMaker Pro, version 10.0, File-Maker Inc, Santa Clara, CA). Clustered data were analyzed statistically using the Statistical Package for the Social Sciences (SPSS) for Windows (version 20.0.0, SPSS, Inc., Chicago, IL).

\section{RESULTS}

\section{Age and sex}

There were $615(81.7 \%)$ male and 138 (18.3\%) female patients, with a male to female ratio of $4.4: 1$. The age of the patients ranged from 17 to 90 years, and the mean age $( \pm \mathrm{SD})$ was $36.2( \pm 16.3)$ years. In both sexes, the highest incidence of mandibular fractures $(n=367,48.7 \%)$ was observed in the age group of 17-30 years, and the most frequently affected patients were males in this age group ( $\mathrm{n}=301,40.0 \%)$ (Fig. 1).

\section{Etiology}

All of the fractures treated in our department were traumatic fractures of the mandible. Traffic accidents

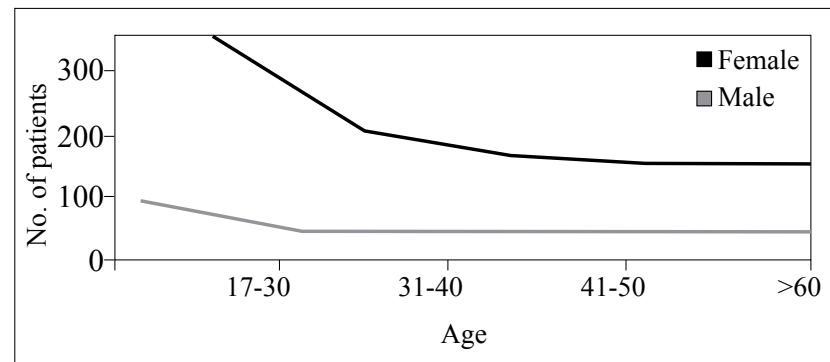

Fig. 1. Distribution of patients according to age and sex.

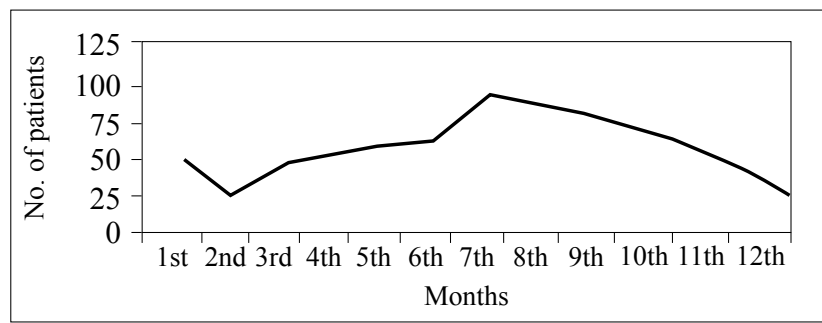

Fig. 2. Monthly distribution of patients.

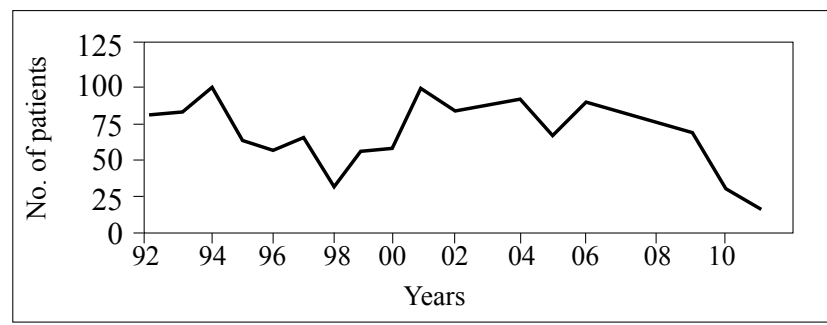

Fig. 3. Yearly distribution of patients.

were the primary causative factor of mandibular fractures in all age groups and both sexes. While the overall ratio of traffic accidents was $54.3 \%, 38.2 \%$ occurred as a result of in-vehicle accidents, $8.8 \%$ were due to pedestrian accidents and $7.3 \%$ to motorcycle-related accidents. The other causes of mandibular fractures were assault, falls, industrial injuries, gunshot injuries, and others (include sporting and animal-related injuries). All of the causative factors accounted for the highest number in the age group of 17-30 years. Motorcyclerelated injuries, industrial injuries, and etiologies including violence, such as assault and gunshot injuries, were most commonly observed among male patients. Among females, only one patient had trauma due to motorcycle-related injury and none had trauma due to gunshot injury (Tables 1, 2). In motorcycle-related injuries, $98 \%$ of the patients were male and $59.2 \%$ were aged $17-30$ years. These rates were $90.6 \%$ and $58.6 \%$ in industrial injuries and $100 \%$ and $68.7 \%$ in gunshot injuries, respectively.

\section{Monthly and yearly distribution}

Figure 2 shows the monthly distribution of mandibular fracture admissions to our department between January 1992 and December 2011. The highest pro- 
Table 1. Etiology of mandibular fractures according to sex and male/female ratio

\begin{tabular}{|c|c|c|c|c|c|c|c|}
\hline \multirow[t]{2}{*}{ Mechanism of injury } & \multicolumn{2}{|c|}{ Male } & \multicolumn{2}{|c|}{ Female } & \multicolumn{2}{|c|}{ Total } & \multirow[t]{2}{*}{ Male/Female } \\
\hline & $\mathrm{n}$ & $\%$ & $\mathrm{n}$ & $\%$ & $\mathrm{n}$ & $\%$ & \\
\hline \multicolumn{8}{|l|}{ Traffic accident } \\
\hline In-vehicle & 222 & 36.1 & 66 & 47.8 & 288 & 38.2 & $1 / 1.32$ \\
\hline Pedestrian & 50 & 8.1 & 16 & 11.6 & 66 & 8.8 & $1 / 1.43$ \\
\hline Motorcycle & 54 & 8.8 & 1 & 0.7 & 55 & 7.3 & $1 / 0.08$ \\
\hline Assault & 129 & 21.0 & 14 & 10.1 & 143 & 19.0 & $1 / 0.5$ \\
\hline Falls & 107 & 17.4 & 35 & 25.4 & 142 & 18.8 & $1 / 1.46$ \\
\hline Industrial injury & 29 & 4.7 & 3 & 2.2 & 32 & 4.3 & $1 / 0.47$ \\
\hline Gunshot injury & 16 & 2.6 & 0 & 0.0 & 16 & 2.1 & $1 / 0$ \\
\hline Others & 8 & 1.3 & 3 & 2.2 & 11 & 1.5 & $1 / 1.7$ \\
\hline Total & 615 & 100.0 & 138 & 100.0 & 753 & 100 & \\
\hline
\end{tabular}

Table 2. Etiology of mandibular fractures according to age category (years)

\begin{tabular}{|c|c|c|c|c|c|c|c|c|c|c|c|c|}
\hline \multirow{2}{*}{$\begin{array}{l}\text { Mechanism of } \\
\text { injury }\end{array}$} & \multicolumn{2}{|c|}{$17-30$} & \multicolumn{2}{|c|}{$31-40$} & \multicolumn{2}{|c|}{$41-50$} & \multicolumn{2}{|c|}{$51-60$} & \multicolumn{2}{|c|}{$>60$} & \multicolumn{2}{|c|}{ Total } \\
\hline & $\mathrm{n}$ & $\%$ & $\mathrm{n}$ & $\%$ & $\mathrm{n}$ & $\%$ & $\mathrm{n}$ & $\%$ & $\mathrm{n}$ & $\%$ & $\mathrm{n}$ & $\%$ \\
\hline \multicolumn{13}{|l|}{ Traffic accident } \\
\hline In-vehicle & 137 & 37.3 & 62 & 43.7 & 43 & 44.8 & 26 & 32.1 & 20 & 29.9 & 288 & 38.2 \\
\hline Pedestrian & 29 & 7.9 & 13 & 9.2 & 7 & 7.3 & 10 & 12.3 & 7 & 10.4 & 66 & 8.8 \\
\hline Motorcycle & 33 & 9.0 & 8 & 5.6 & 8 & 8.3 & 3 & 3.7 & 3 & 4.5 & 55 & 7.3 \\
\hline Assault & 69 & 18.8 & 30 & 21.1 & 14 & 14.6 & 11 & 13.6 & 19 & 28.4 & 143 & 19.0 \\
\hline Falls & 64 & 17.4 & 19 & 13.4 & 18 & 18.8 & 27 & 33.3 & 14 & 20.9 & 142 & 18.9 \\
\hline Industrial injury & 18 & 4.9 & 8 & 5.6 & 2 & 2.1 & 2 & 2.5 & 2 & 3.0 & 32 & 4.2 \\
\hline Gunshot injury & 11 & 3.0 & 1 & 0.7 & 3 & 3.1 & 1 & 1.2 & 0 & 0.0 & 16 & 2.1 \\
\hline Others & 6 & 1.6 & 1 & 0.7 & 1 & 1.0 & 1 & 1.2 & 2 & 3.0 & 11 & 1.5 \\
\hline Total & 367 & 100.0 & 142 & 100.0 & 96 & 100.0 & 81 & 100.0 & 67 & 100.0 & 753 & 100.0 \\
\hline
\end{tabular}

Table 3. Anatomic sites of fractures according to age category (years)

\begin{tabular}{|c|c|c|c|c|c|c|c|c|c|c|c|c|}
\hline \multirow[t]{2}{*}{ Localization } & \multicolumn{2}{|c|}{$17-30$} & \multicolumn{2}{|c|}{$31-40$} & \multicolumn{2}{|c|}{$41-50$} & \multicolumn{2}{|c|}{$51-60$} & \multicolumn{2}{|c|}{$>60$} & \multicolumn{2}{|c|}{ Total } \\
\hline & $\mathrm{n}$ & $\%$ & $\mathrm{n}$ & $\%$ & $\mathrm{n}$ & $\%$ & $\mathrm{n}$ & $\%$ & $\mathrm{n}$ & $\%$ & $\mathrm{n}$ & $\%$ \\
\hline Parasymphysis & 160 & 29.1 & 63 & 31.9 & 27 & 19.7 & 34 & 31.2 & 28 & 28.3 & 312 & 28.6 \\
\hline Condyle & 116 & 21.1 & 33 & 16.7 & 30 & 21.9 & 25 & 22.9 & 11 & 11.1 & 215 & 19.7 \\
\hline Corpus & 97 & 17.7 & 44 & 22.3 & 28 & 20.4 & 20 & 18.3 & 26 & 26.3 & 215 & 19.7 \\
\hline Angulus & 100 & 18.2 & 30 & 15.2 & 21 & 15.3 & 13 & 11.9 & 18 & 18.2 & 182 & 16.7 \\
\hline Symphysis & 40 & 7.3 & 12 & 6 & 13 & 9.5 & 8 & 7.3 & 7 & 7.1 & 80 & 7.3 \\
\hline DAP & 24 & 4.4 & 12 & 6 & 9 & 6.6 & 6 & 5.5 & 4 & 4 & 55 & 5.1 \\
\hline Ramus & 9 & 1.6 & 3 & 1.5 & 8 & 5.8 & 3 & 2.8 & 4 & 4 & 27 & 2.5 \\
\hline Coronoid process & 3 & 0.5 & 0 & 0 & 1 & 0.7 & 0 & 0 & 0 & 0 & 4 & 0.4 \\
\hline Total & 549 & 100.0 & 197 & 100.0 & 137 & 100.0 & 109 & 100.0 & 98 & 100.0 & 1090 & 100.0 \\
\hline
\end{tabular}

DAP: Dentoalveolar process.

portion was seen in summer $(33.7 \%)$, followed by autumn (29.2\%), spring (21.5\%) and winter (15.6\%). The highest incidence of mandibular fractures was seen during July, August and September $(12.7 \%, 11.8 \%$ and $11.3 \%$, respectively). The fewest hospital admissions due to mandibular fracture were seen in December and February (5.6\% and 3.9\%, respectively). Figure
3 shows the yearly distribution of admissions to our department. The highest number of admitted patients was in $2001(7.4 \%)$ and the lowest in 2011 (1.3\%).

\section{Fracture Localizations and Patterns}

Because some patients had more than one mandibular fracture line, 753 patients showed 1090 fractures, 
Table 4. Anatomic sites of fractures according to sex and male/female ratio

\begin{tabular}{|c|c|c|c|c|c|c|c|}
\hline \multirow[t]{2}{*}{ Localization } & \multicolumn{2}{|c|}{ Male } & \multicolumn{2}{|c|}{ Female } & \multicolumn{2}{|c|}{ Total } & \multirow[t]{2}{*}{ Male/Female } \\
\hline & $\mathrm{n}$ & $\%$ & $\mathrm{n}$ & $\%$ & $\mathrm{n}$ & $\%$ & \\
\hline Parasymphysis & 254 & 28.3 & 58 & 29.9 & 312 & 28.6 & $1 / 1.05$ \\
\hline Condyle & 185 & 20.7 & 30 & 15.5 & 215 & 19.7 & $1 / 0.75$ \\
\hline Corpus & 166 & 18.5 & 49 & 25.2 & 215 & 19.7 & $1 / 1.36$ \\
\hline Angulus & 157 & 17.5 & 25 & 12.9 & 182 & 16.7 & $1 / 0.74$ \\
\hline Symphysis & 64 & 7.1 & 16 & 8.2 & 80 & 7.3 & $1 / 0$ \\
\hline Dentoalveolar process & 45 & 5.1 & 10 & 5.2 & 55 & 5.1 & $1 / 1.02$ \\
\hline Ramus & 21 & 2.4 & 6 & 3.1 & 27 & 2.5 & $1 / 1.29$ \\
\hline Coronoid process & 4 & 0.4 & 0 & 0 & 4 & 0.4 & $1 / 0$ \\
\hline Total & 896 & 100.0 & 194 & 100.0 & 1090 & 100.0 & \\
\hline
\end{tabular}

Table 5. Distribution of fracture pattern according to age category (years)

\begin{tabular}{|c|c|c|c|c|c|c|c|c|c|c|c|c|}
\hline \multirow[t]{2}{*}{ Pattern } & \multicolumn{2}{|c|}{$17-30$} & \multicolumn{2}{|c|}{$31-40$} & \multicolumn{2}{|c|}{$41-50$} & \multicolumn{2}{|c|}{$51-60$} & \multicolumn{2}{|c|}{$>60$} & \multicolumn{2}{|c|}{ Total } \\
\hline & $\mathrm{n}$ & $\%$ & $\mathrm{n}$ & $\%$ & $\mathrm{n}$ & $\%$ & $\mathrm{n}$ & $\%$ & $\mathrm{n}$ & $\%$ & $\mathrm{n}$ & $\%$ \\
\hline $\begin{array}{l}\text { Unilateral single } \\
\text { fracture }\end{array}$ & 208 & 56.7 & 88 & 62.0 & 61 & 63.5 & 53 & 65.4 & 38 & 56.7 & 448 & 59.5 \\
\hline $\begin{array}{l}\text { Unilateral multiple } \\
\text { fracture }\end{array}$ & 45 & 12.2 & 22 & 15.5 & 14 & 14.6 & 13 & 16.1 & 6 & 9.0 & 100 & 13.3 \\
\hline $\begin{array}{l}\text { Bilateral multiple } \\
\text { fracture }\end{array}$ & 114 & 31.1 & 32 & 22.5 & 21 & 21.9 & 15 & 18.5 & 23 & 34.3 & 205 & 27.2 \\
\hline Total & 367 & 100.0 & 142 & 100.0 & 96 & 100.0 & 81 & 100.0 & 67 & 100.0 & 753 & 100.0 \\
\hline
\end{tabular}

Table 6. Distribution of fracture pattern according to sex and male/female ratio

\begin{tabular}{|c|c|c|c|c|c|c|c|}
\hline \multirow[t]{2}{*}{ Pattern } & \multicolumn{2}{|c|}{ Male } & \multicolumn{2}{|c|}{ Female } & \multicolumn{2}{|c|}{ Total } & \multirow[t]{2}{*}{ Male/Female } \\
\hline & $\mathrm{n}$ & $\%$ & $\mathrm{n}$ & $\%$ & $\mathrm{n}$ & $\%$ & \\
\hline Unilateral single fracture & 362 & 58.9 & 86 & 62.3 & 448 & 59.5 & $1 / 1.06$ \\
\hline Unilateral multiple fracture & 84 & 13.7 & 16 & 11.6 & 100 & 13.3 & $1 / 0.85$ \\
\hline Bilateral multiple fracture & 169 & 27.4 & 36 & 26.1 & 205 & 27.2 & $1 / 0.95$ \\
\hline Total & 615 & 100.0 & 138 & 100.0 & 753 & 100.0 & \\
\hline
\end{tabular}

averaging 1.45 fractures per mandible. In both sexes and all age groups, the most affected site of the mandible was the parasymphysis (Tables 3,4), followed respectively by the condyle and corpus below the age of 50 years and the corpus and condyle above the age of 50 years, respectively (Figs. 4,5 ).

There was only a single fracture line in $448(59.5 \%)$, unilateral multiple fracture lines in $100(13.3 \%)$ and bilateral multiple fracture lines in 205 (27.2\%) patients. Regarding the distribution of fracture patterns beyond age groups and sexes, unilateral single fracture pattern had the highest incidence (Tables 5, 6). The most common fracture localization was the parasymphysis (134/448) followed by the corpus (103/448) in single fractured patients (Table 7). Condyle + symphysis
$(16 / 100)$ in unilateral multiple fractures and parasymphysis + condyle (43/205) in bilateral multiple fractures were the most common combinations (Tables $8,9)$. Twenty-nine patients displayed 3 fracture lines $(2.8 \%)$ and 7 patients displayed 4 fracture lines $(0.9 \%)$. The mandibular fractures caused by traffic accidents were most commonly localized at the parasymphysis and corpus, whereas fractures caused by falls were at the parasymphysis and condyle and those caused by assault were at the parasymphysis and angulus (Fig. $6)$. Thirty-four patients $(4.5 \%)$ had a mandibular fracture line that opened to the oral mucosa.

\section{Accompanying Traumas}

Although $80.2 \%(\mathrm{n}=604)$ of the patients had isolated mandibular fracture, $19.8 \%(\mathrm{n}=149)$ had accom- 


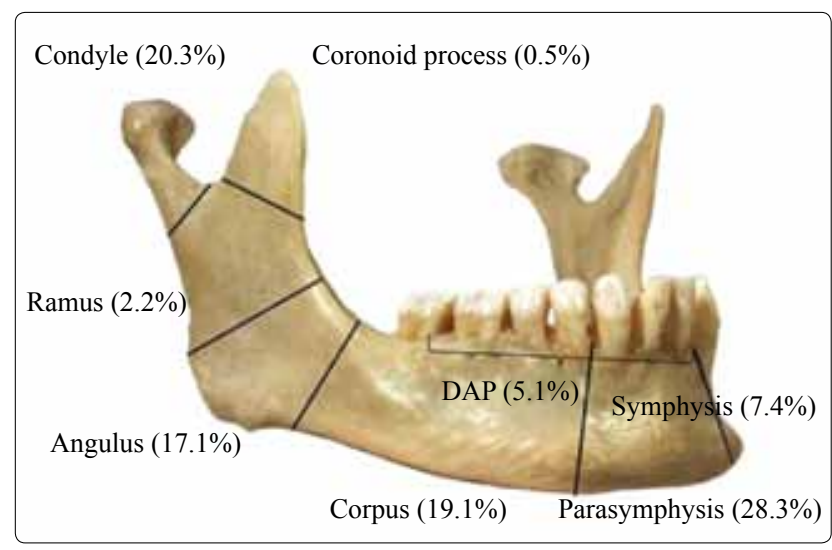

Fig. 4. Distribution of fracture localizations below the age of 50. (Color figure can be viewed in the online issue, which is available at www.tjtes.org).

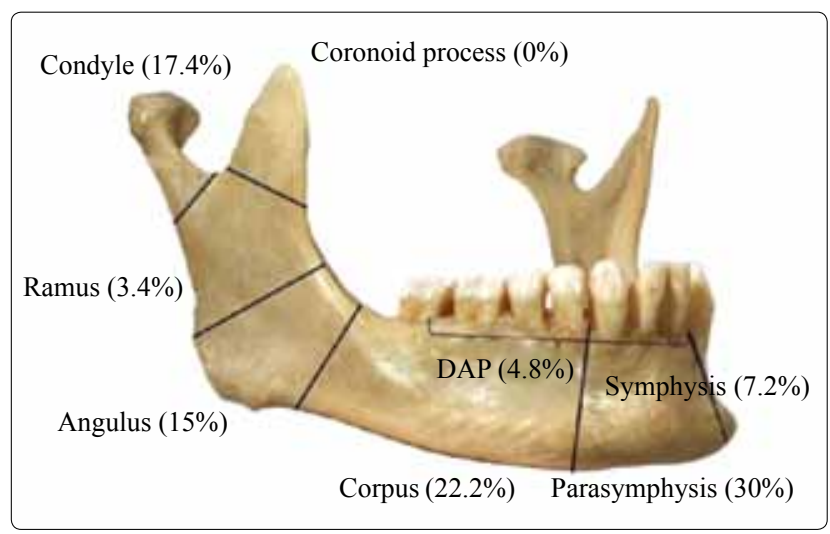

Fig. 5. Distribution of fracture localizations above the age of 50. (Color figure can be viewed in the online issue, which is available at www.tjtes.org).

panying fractures in the other facial bones. As several patients had more than one injury, 149 patients showed 155 facial fractures. The most common associated facial fracture was the zygomatic fracture followed by Le Fort fractures (Table 10).

Two hundred and seventy-one (36\%) patients showed 389 accompanying injuries of other systems. Cranial injuries were the most common, followed by orthopedic, thoracal and intraabdominal injuries, respectively (Table 11). Twenty-eight patients (3.7\%) who had accompanying cranial and other system injuries exhibited a mortal course.

\section{Treatment Method and Period}

We could not apply follow-up and treatment in 45 $(6 \%)$ patients due to mortal course $(n=28)$ or refusal of treatment $(\mathrm{n}=17)$. In $25(3.3 \%)$ patients with fissurelike, non-displaced fracture, no reduction technique was applied. These patients underwent a symptomatic treatment consisting of analgesics, oral rinse and soft diet. Closed reduction with elastic bandage, arch bar, quick-fix screws, or Ivy Loop was the only method performed in $280(37.2 \%)$ patients. Osteosynthesis by open reduction and internal fixation (miniplates, screws or transosseous wiring) was performed on 403 $(53.5 \%)$ patients; closed reduction techniques were also carried out in 134 of these patients. The distribution of the treatment methods shows that open reduction and internal fixation with or without closed reduction was the most common technique used for all the patients (Table 12). $54.3 \%$ of the patients who underwent a reduction technique $(\mathrm{CR}, \mathrm{OR}$ or $\mathrm{OR}+\mathrm{CR})$ were

Table 7. Anatomic localizations of single fractures in 448 patients

\begin{tabular}{lc}
\hline Localization & $\mathrm{n}$ \\
\hline Parasymphysis & 134 \\
Corpus & 103 \\
Condyle & 78 \\
Angulus & 68 \\
Symphysis & 40 \\
Dentoalveolar process & 13 \\
Ramus & 11 \\
Coronoid process & 1 \\
Total & 448 \\
\hline
\end{tabular}

Table 8. Anatomic localizations of unilateral multiple fractures in 100 patients

\begin{tabular}{lc}
\hline Localization & $\mathrm{n}$ \\
\hline Condyle+symphysis & 16 \\
Parasymphysis+dentoalveolar process & 13 \\
Corpus+angulus & 8 \\
Parasymphysis + condyle & 7 \\
Symphysis+dentoalveolar process & 7 \\
Parasymphysis+angulus & 6 \\
Parasymphysis+symphysis & 6 \\
Condyle+corpus & 5 \\
Corpus + dentoalveolar process & 5 \\
Condyle+angulus & 4 \\
Condyle+dentoalveolar process & 4 \\
Corpus+symphysis+dentoalveolar process & 3 \\
Angulus+symphysis & 2 \\
Parasymphysis+corpus & 2 \\
Parasymphysis + symphysis+dentoalveolar process & 2 \\
Symphysis+ramus & 2 \\
Angulus + corpus & 1 \\
Angulus+ramus & 1 \\
Condyle+corpus + dentoalveolar process & 1 \\
Condyle+symphysis + dentoalveolar process & 1 \\
Corpus+symphysis & 1 \\
Parasymphysis+angulus + dentoalveolar process & 1 \\
Parasymphysis + corpus + ram + dentoalveolar process & 1 \\
Symphysis+angulus & 1 \\
Total & 100 \\
\hline
\end{tabular}


Table 9. Anatomic localizations of bilateral multiple fractures in 235 patients

\begin{tabular}{|c|c|}
\hline Localization & $\mathrm{n}$ \\
\hline Parasymphysis + condyle & 43 \\
\hline Parasymphysis + angulus & 36 \\
\hline Corpus+angulus & 22 \\
\hline Condyle+corpus & 15 \\
\hline Bilateral corpus & 13 \\
\hline Bilateral parasymphysis & 13 \\
\hline Parasymphysis + corpus & 10 \\
\hline Bilateral angulus & 6 \\
\hline Condyle+angulus & 6 \\
\hline Parasymphysis+ramus & 4 \\
\hline Symphysis+bilateral condyle & 4 \\
\hline Corpus+ramus & 3 \\
\hline Bilateral condyle & 2 \\
\hline Condyle+bilateral parasymphysis & 2 \\
\hline Parasymphysis+angulus+ramus & 2 \\
\hline Parasymphysis+bilateral angulus & 2 \\
\hline Angulus+bilateral parasymphysis & 1 \\
\hline Angulus + corpus & 1 \\
\hline Angulus+ramus & 1 \\
\hline Symphysis+bilateral condyle & 1 \\
\hline Symphysis+coronoid process + bilateral condyle & 1 \\
\hline DAP & 1 \\
\hline Condyle+angulus + ramus & 1 \\
\hline Condyle+bilateral corpus & 1 \\
\hline Condyle + corpus + angulus & 1 \\
\hline Condyle + corpus + ramus & 1 \\
\hline Condyle+symphysis & 1 \\
\hline Corpus+bilateral angulus & 1 \\
\hline Parasymphysis+bilateral condyle & 1 \\
\hline Parasymphysis+DAP+bilateral condyle & 1 \\
\hline Parasymphysis + condyle+angulus & 1 \\
\hline Parasymphysis + condyle + coronoid process + DAP & 1 \\
\hline Parasymphysis + condyle+corpus & 1 \\
\hline Parasymphysis + condyle + corpus + DAP & 1 \\
\hline Parasymphysis + coronoid process & 1 \\
\hline Parasymphysis + coronoid process + bilateral condyle & 1 \\
\hline Parasymphysis+symphysis+bilateral condyle & 1 \\
\hline Symphysis+bilateral parasymphysis & 1 \\
\hline Total & 205 \\
\hline
\end{tabular}

DAP: Dentoalveolar process.

treated within the first day, $25.2 \%$ between the 2nd4th days, $10 \%$ between the 5 th- 7 th days, and $10.5 \%$ in more than 7 days (Fig. 7).

\section{Complications}

Sixty-one $(8.1 \%)$ patients showed postoperative complications. Complications, in decreasing order of frequency, included occlusion disorder, plate exposition and infection, sensory complications (hypoesthesia, paresthesia), opening at the mucosal sutures, and temporomandibular joint dysfunction. There was no complication among the patients who were treated conservatively. Regarding reduction techniques, the lowest complication rates were observed among patients who underwent closed reduction alone (9/280) and the highest in patients subjected to both open and closed reduction (30/134) (Table 13).

\section{DISCUSSION}

Despite being the heaviest and strongest bone of the face, fracture of the mandible is one of the commonest facial skeletal injuries for the following reasons: 1) It is an open arch; 2) It is located in the lower portion of the face; 3 ) It is the mechanism of hyperextension and hyperflexion of the head in traffic accidents; and 4) It atrophies as a result of aging. ${ }^{[16]}$ The primary causative factor of mandibular fractures in developing countries is traffic accidents, ${ }^{[2,3,-9]}$ whereas interpersonal violence is the major cause of this trauma in developed countries. ${ }^{[10-14]}$ In the literature, there are some reports from developed countries ${ }^{[4,17]}$ indicating traffic accidents as the most frequent cause of mandibular injury. Poor roads and inadequate enforcement of road safety regulations and speed limits are some of the factors that have accounted for the higher incidence of traffic accidents in developing countries. ${ }^{[7]}$ James et al. ${ }^{[18]}$ explained that epidemiologic factors in mandibular fractures had changed with the advent of lower speed limits, seatbelt and helmet laws, and increased urban violence. In the present report conducted in a developing country, Turkey, traffic accidents were the primary causative factor of mandibular fractures in both sexes and in all age groups. The results of the present report

Table 10. Distribution of additional maxillofacial trauma

\begin{tabular}{lc}
\hline Localization & $\mathrm{n}$ \\
\hline Zygoma & 63 \\
Maxillary dentoalveolar process & 10 \\
Nasal bone & 7 \\
Nasoorbitoethmoid & 3 \\
Le Fort I-III & 57 \\
Frontal sinus & 3 \\
Panfacial & 12 \\
Total & 155 \\
\hline
\end{tabular}

Table 11. Distribution of additional traumas of other systems

\begin{tabular}{lc}
\hline Localization & $\mathrm{n}$ \\
\hline Cranial & 154 \\
Orthopedic & 137 \\
Thoracal & 64 \\
Intraabdominal & 34 \\
Total & 289 \\
\hline
\end{tabular}


Table 12. Management of mandibular fractures

\begin{tabular}{|c|c|c|c|c|c|c|c|c|c|}
\hline \multirow[t]{2}{*}{ Conservative } & \multicolumn{4}{|c|}{$\mathrm{CR}(\mathrm{n}=280)$} & \multicolumn{2}{|c|}{ OR $(n=403)$} & \multicolumn{2}{|c|}{ Not treated $(n=45)$} & \multirow[t]{2}{*}{ Total } \\
\hline & Arch bar & Quick-fix & $\begin{array}{l}\text { Ivy } \\
\text { Loop }\end{array}$ & $\begin{array}{c}\text { Elastic } \\
\text { bandage }\end{array}$ & With CR & $\begin{array}{c}\text { Without } \\
\text { CR }\end{array}$ & Exitus & Rejection & \\
\hline 25 & 267 & 3 & 4 & 6 & 134 & 269 & 28 & 17 & 753 \\
\hline 3.3 & 35.5 & 0.4 & 0.5 & 0.8 & 17.8 & 35.7 & 3.7 & 2.3 & 100 \\
\hline
\end{tabular}

CR: Closed reduction; OR: Open reduction.

Table 13. Distribution of postoperative complications according treatment method

\begin{tabular}{lcccc}
\hline & \multicolumn{4}{c}{ Treatment } \\
\cline { 2 - 5 } Complication & Closed reduction & Open reduction & Open reduction+Closed reduction & Total \\
\hline Malocclusion & 7 & 3 & 7 & 17 \\
Temporomandibular joint dysfunction & - & 2 & 1 & 3 \\
Exposition of plate & - & 3 & 10 & 13 \\
Infection & 2 & 4 & 7 & 13 \\
Opening mucosal sutures & - & 3 & 2 & 5 \\
Sensory complications & - & 7 & 3 & 10 \\
Total & 9 & 22 & 30 & 61 \\
\hline
\end{tabular}

are in agreement with the previous reports regarding age and sex. There was a predominance of male patients over females, with a ratio of $4.4: 1$, and it was similar to the reported overall ratios that have ranged between 2.9:1 and 5:1..$^{[5-9,12,13,17]}$ The most affected patients were males aged $17-30$ years $(n=301,40 \%)$, which is in agreement with the literature. ${ }^{[5-9,13]}$ Motorcycle-related injuries, industrial injuries and etiologies including violence, such as assault and gunshot injuries, were most commonly observed in male patients aged 17-30 years. The explanation may be that males in this age group are most likely to be involved in violence, and they also drive vehicles carelessly and participate in dangerous exercises and sports. ${ }^{[8]}$ Moreover, according to the distribution of cases by months, mandibular fractures exhibited a considerable increase during the summer (July, August, September). Because Turkish families prefer the summer months for their

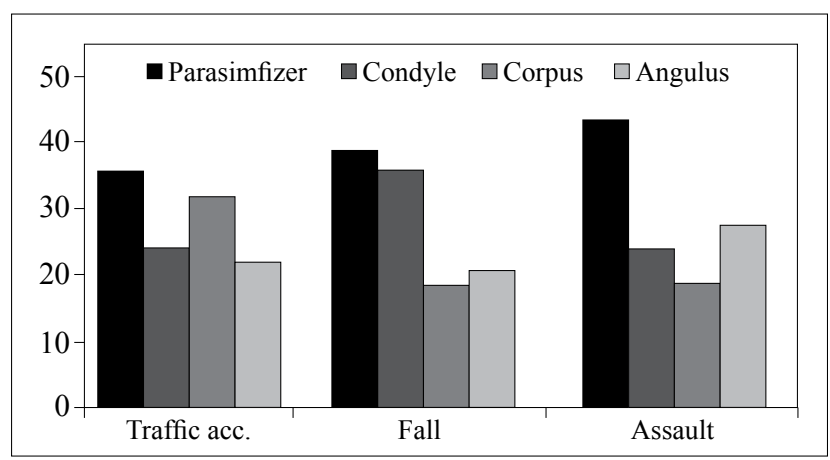

Fig. 6. Distribution of fracture localizations according to etiology. holidays, thereby causing traffic congestion, the incidence of traffic accidents soars during that period. ${ }^{[15]}$ Similar to the previous reports ${ }^{[5-8]}$ (range, 45.3-64.3\%), there was only a single fracture line in 448 patients $(59.5 \%)$, while 305 patients $(40.5 \%)$ had more than one fracture line. Many authors reported the condyle as the most frequently affected site, ${ }^{[2,4,9,10,17]}$ whereas others reported this to be the parasymphysis ${ }^{[3,5,7,12]}$ and angulus. ${ }^{[8,19]}$ The most affected sites of the mandible in the present report below the age of 50 years werre the parasymphysis, condyle and corpus, whereas these were the parasymphysis, corpus and condyle, respectively, above the age of 50 years. Similar to a previous report, ${ }^{[7]}$ the most common combination of fracture site was the parasymphysis and condyle. In this report, it was observed that fractures of the anterior region of the mandible (parasymphysis and symphysis) were likely to be combined with fractures of the posterior

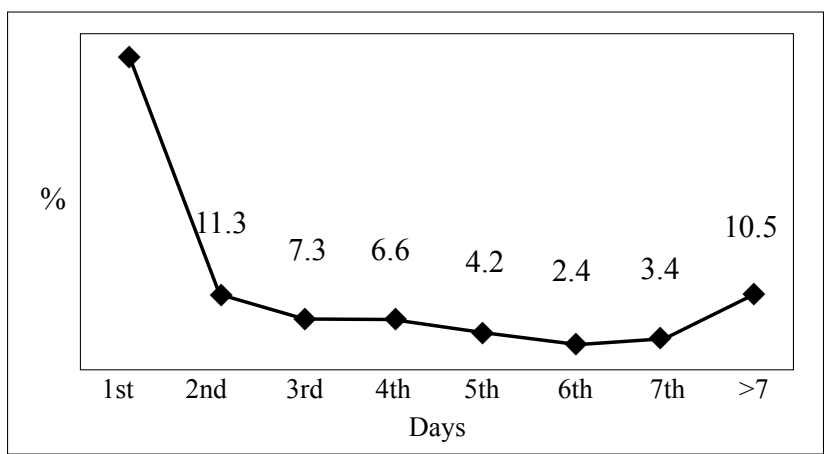

Fig. 7. Distribution of patients according to treatment period. 
region, the condyle and angulus. A correlation between the mechanism of injury and fracture localization was shown in the present report. Particularly in agreement with the report of Atilgan et al., ${ }^{[2]}$ the most affected regions of the mandible were the parasymphysis and corpus due to traffic accidents, the parasymphysis and condyle due to falls, and the parasymphysis and angulus due to assault (Fig. 6). Individuals involved in motor vehicle collisions present to emergency departments with a variety of associated injuries. ${ }^{[21]}$ Although $80.2 \%(n=604)$ of the patients had isolated mandibular fracture, $19.8 \%(n=149)$ had accompanying fractures of other facial bones, especially zygomatic and Le Fort I-III. In the literature, ${ }^{[5-9,12]}$ the incidence of accompanying facial fractures ranged from 5-30\%. Furthermore, 271 patients (36\%) had accompanying traumas of other systems. The leading accompanying additional trauma was cranial injury.

In the present report, open reduction and internal fixation with miniplates, screws or transosseous wiring $(\mathrm{n}=403,53.5 \%)$ was the most frequently applied method for the treatment of the mandibular fractures. $54.3 \%$ of the patients who underwent a certain reduction technique were treated within the first day. The time between the injury and surgery depends on factors such as good clinical condition to tolerate a surgical procedure and the admission time of the patient. Hermund et al. ${ }^{[22]}$ showed that there is presently no strong evidence for either acute or delayed treatment of mandibular fractures in order to minimize postoperative complications. A postoperative complication rate of $8.1 \%$ was observed in the present report. The highest complication rates were observed among patients who underwent both open and closed reduction. The most common complication was malocclusion followed by plate exposition and infection, respectively. The incidence of postoperative infection was $1.7 \%$, and this was definitively lower than the data reported previously. ${ }^{[2,5,6,9,13]}$

In conclusion, in this clinical series, the most frequently affected patients were males aged 17-30 years, and the most affected site of the mandible was the parasymphysis. The most common causative factor of mandibular fracture was motor vehicle accidents. However, in recent years, increased double-road construction, traffic audits and regulation of the traffic rules have decreased the incidence of mandibular fractures.

Conflict-of-interest issues regarding the authorship or article: None declared.

\section{REFERENCES}

1. Bakardjiev A, Pechalova P. Maxillofacial fractures in Southern Bulgaria - a retrospective study of 1706 cases. J Craniomaxillofac Surg 2007;35:147-50.
2. Brasileiro BF, Passeri LA. Epidemiological analysis of maxillofacial fractures in Brazil: a 5-year prospective study. Oral Surg Oral Med Oral Pathol Oral Radiol Endod 2006;102:2834.

3. Aksoy E, Unlü E, Sensöz O. A retrospective study on epidemiology and treatment of maxillofacial fractures. J Craniofac Surg 2002;13:772-5.

4. Iida S, Kogo M, Sugiura T, Mima T, Matsuya T. Retrospective analysis of 1502 patients with facial fractures. Int J Oral Maxillofac Surg 2001;30:286-90.

5. Patrocínio LG, Patrocínio JA, Borba BH, Bonatti Bde S, Pinto LF, Vieira JV, et al. Mandibular fracture: analysis of 293 patients treated in the Hospital of Clinics, Federal University of Uberlândia. Braz J Otorhinolaryngol 2005;71:560-5.

6. Adeyemo WL, Iwegbu IO, Bello SA, Okoturo E, Olaitan AA, Ladeinde AL, et al. Management of mandibular fractures in a developing country: a review of 314 cases from two urban centers in Nigeria. World J Surg 2008;32:2631-5.

7. Krishnaraj S, Chinnasamy R. A 4-year retrospective study of mandibular fractures in a South Indian city. J Craniofac Surg 2007; 18:776-80.

8. Sakr K, Farag IA, Zeitoun IM. Review of 509 mandibular fractures treated at the University Hospital, Alexandria, Egypt. Br J Oral Maxillofac Surg 2006;44:107-11.

9. de Matos FP, Arnez MF, Sverzut CE, Trivellato AE. A retrospective study of mandibular fracture in a 40-month period. Int J Oral Maxillofac Surg 2010;39:10-5.

10. Iida S, Hassfeld S, Reuther T, Schweigert HG, Haag C, Klein J, et al. Maxillofacial fractures resulting from falls. J Craniomaxillofac Surg 2003;31:278-83.

11. Rocton S, Chaine A, Ernenwein D, Bertolus C, Rigolet A, Bertrand JC, et al. Mandibular fractures: epidemiology, therapeutic management, and complications in a series of 563 cases. Rev Stomatol Chir Maxillofac 2007;108:3-12.

12. Czerwinski M, Parker WL, Chehade A, Williams HB. Identification of mandibular fracture epidemiology in Canada: Enhancing injury prevention and patient evaluation. Can J Plast Surg 2008;16:36-40.

13. Sojot AJ, Meisami T, Sandor GK, Clokie CM. The epidemiology of mandibular fractures treated at the Toronto general hospital: A review of 246 cases. J Can Dent Assoc 2001;67:640-4.

14. Erdmann D, Follmar KE, Debruijn M, Bruno AD, Jung SH, Edelman D, et al. A retrospective analysis of facial fracture etiologies. Ann Plast Surg 2008;60:398-403.

15.Eskitascioglu T, Ozyazgan I, Coruh A, Gunay GK, Yuksel E. Retrospective analysis of two hundred thirty-five pediatric mandibular fracture cases. Ann Plast Surg 2009;63:52230.

16. Holt RG. Maxillofacial trauma. In: Otolaryngology head and neck surgery. Mosby Company; 1986. p. 313-4.

17. Bormann KH, Wild S, Gellrich NC, Kokemüller H, Stühmer C, Schmelzeisen R, et al. Five-year retrospective study of mandibular fractures in Freiburg, Germany: incidence, etiology, treatment, and complications. J Oral Maxillofac Surg 2009;67:1251-5.

18. James RB, Fredrickson C, Kent JN. Prospective study of mandibular fractures. J Oral Surg 1981;39:275-81.

19. Olson RA, Fonseca RJ, Zeitler DL, Osbon DB. Fractures of the mandible: a review of 580 cases. J Oral Maxillofac Surg 1982;40:23-8.

20. Atilgan S, Erol B, Yaman F, Yilmaz N, Ucan MC. Mandibu- 
lar fractures: a comparative analysis between young and adult patients in the southeast region of Turkey. J Appl Oral Sci 2010;18:17-22.

21. Fischer K, Zhang F, Angel MF, Lineaweaver WC. Injuries associated with mandible fractures sustained in motor ve- hicle collisions. Plast Reconstr Surg 2001;108:328-31.

22. Hermund NU, Hillerup S, Kofod T, Schwartz O, Andreasen JO. Effect of early or delayed treatment upon healing of mandibular fractures: a systematic literature review. Dent Traumatol 2008;24:22-6. 